\title{
A study on the Improvement of the Industry-academic Adjunct Teacher System and the Satisfaction Improvement Plan of Military Specialized High Schools
}

\author{
군특성화고 산학 겸임교사 제도 개선 및 \\ 만족도 향상 방안 \\ Yun-Jeong Kim¹, Se-Hun Park ${ }^{2}$ \\ 김윤정 ${ }^{1}$, 박세훈 2 \\ ${ }^{1}$ Professor, Dep. Health, Counselling and Welfare, Hanseo University, Republic of Korea, \\ twoyun21@hanmail.net \\ ${ }^{2}$ Senior Research Fellow, Korea Legislation Research Institute, Republic of Korea, \\ lawpark@klri.re.kr
}

Corresponding author: Se-Hun Park

\begin{abstract}
The purpose of this study is to first, deduce the limitations of the industry-academic adjunct teacher system at military-specialized high schools. Second, analyze the satisfaction of industryacademic adjunct teachers and system improvement plans. Third, make suggestions for the establishment of the industry-academic adjunct teacher system. In order to achieve these purpose, a survey was conducted for students enrolled in specialized military high schools and military service personnel as well as by reviewing the literature related to industry-university adjunct teachers. As a result of the study, first, it was difficult to evaluate the qualifications of industrial-educational adjunct teachers, the principal's authority in recruiting and managing teachers was weak, the problem of equity with other industrial-academic adjunct teachers, and the problem of operating essential manpower as contract workers were revealed. Second, the satisfaction with professionalism, classes, and counseling of the industry-academic adjunct teachers was higher among the students enrolled in military specialized high schools, but the military serviceman demanded higher levels of competency enhancement and status security information of the industry-academic adjunct teachers. In addition, the military serviceman rated the correspondence between the information about military service obtained in high school and the current situation somewhat low. Based on these results, a plan to improve the industryacademic adjunct teacher system at military specialized high schools and a plan to improve the satisfaction of current students and military serviceman were proposed.
\end{abstract}

Keywords: Military Specialized High School, Industry-academic Adjunct Teachers, Satisfaction, System Improvement Plan, Soldier, Short-term Non-commissioned Officer

요약: 본 연구의 목적은 첫째, 군특성화고 산학 겸임교사 제도의 제한점을 도출하고, 둘째, 군특성화고 산학 겸임교사에 대한 만족도 및 제도개선 방안을 분석하고, 셋째, 군특성화고

Received: August 11, 2021; $1^{\text {st }}$ Review Result: September 28, 2021; $2^{\text {nd }}$ Review Result: November 13, 2021 Accepted: December 31, 2021

*본 연구는 이수정, 허영준, 이미란, 송기원, 김윤정, 박상혁(2021)의 '군특성화고 운영 개선방안 연구. 한국직업능력개발원.한국장학재단’의 일부를 수정보완하였다. 
산학 겸임교사 제도의 정착을 위한 제언을 하는 것이다. 이를 위해 산학 겸임교사 관련 법령 문헌고찰 및 군특성화고 재학생과 군복무자 대상으로 설문조사를 하였다. 연구 결과, 첫째, 군특성화고 산학 겸임교사의 자질평가가 어려우며, 교사의 모집 및 운영에서 학교장의 권한이 약하고, 다른 산학 겸임교사와의 형평성 문제, 필수인력을 계약직으로 운영하는 문제점이 도출되었다. 둘째, 산학 겸임교사의 전문성이나 수업, 상담에 대한 만족도는 군특성화고 재학생이 더 높았으나, 산학 겸임교사의 역량 강화나 신분안정보장은 군복무자가 좀 더 높게 요구하고 있었다. 또한, 졸업한 군복무자는 고등학교 때 얻은 군복무에 대한 정보와 현재 상황간의 정보의 일치성을 다소 낮게 평가하였다. 이러한 결과를 토대로 하여 군특성화고 산학 겸임교사 제도 개선방안과 재학생과 군복무자의 산학 겸임교사에 대한 만족도 향상방안을 제안하였다.

핵심어: 군특성화고, 산학 겸임교사, 만족도, 제도개선방안, 의무복무병, 단기복무부사관

\section{1. 서론}

저출산 고령화 및 병 복무기간의 축소로 2022년 이후 병역자원이 부족해질 것으로 예측되고 있다. 여기에 장기화되고 있는 경제 침체로 인해 국방 분야로의 재정 투입 역시 충분하지 못할 것이라는 예측하에 정부에서는 '국방개혁 2.0'을 수립하였다. ‘국방개혁 2.0'에서는 군 전력증강 소요 예산을 중기계획에 반영하여 추진력을 확보하고, 국방 운영의 효율화 및 인력운영체제의 혁신 등을 계획하였다[1]. 국방인력구조 개편의 주요 방향 중 장교 및 부사관의 계급구조는 초임 간부 획득 전망과 최첨단 장비 운용, 완벽한 전투력 확보 필요성 등을 고려하여 피라미드형에서 항아리형으로 개편하는 것이다[2]. 그러나 인구구조의 변화로 군에서 필요로 하는 인적 자원의 획득이 부족할 것이라는 예측은 오래전부터 있었고[3], 이러한 맥락에서 2007 년부터 군특성화고 제도를 시행하고 있다. 군특성화고는 고등학교 3 학년 시기에 군에서 소요되는 첨단장비 기술인력을 맞춤형으로 교육시켜서, 군복무 중에는 전문분야에 보직되어 경력과 전문성을 개발시키고, 전역 후에는 관련 분야에서 산업 전사로 활용하여 국가 경제 발전에 기여하는 것을 목적으로 한다[4].

군특성화고 교육의 특수성을 고려할 때 군에서의 경험이 풍부한 산학 겸임교사의 역할이 중요하다. 교사가 수행하는 역할은 기본적으로 수업, 학생들의 사회화, 평가자, 생활지도 및 상담 등이 있을 수 있으며 심리적으로는 사회대행자, 판단자, 지식전수자, 지도자, 부모대행자 등의 역할이 있을 수 있다[5]. 군특성화고 산학 겸임교사는 해당 학교장의 통제를 받으며 국방부(각 군)의 군특성화고 지원사업 운영지침을 이행하며, 군특성화고 산학 겸임교사는 별도의 선발 절차를 거쳐 채용(국방부, 2021)되는데, 이들은 군특성화교과 지도 활동뿐만 아니라 군특성화 홍보, 학생 선발, 체험활동, 대군 업무, 태권도 교육, 졸업생 추수 지도 업무를 담당하고 있다[6]. 이처럼 군특성화고 산학 겸임교사는 학생들의 전문교과목에 대한 심화 교육을 담당하면서 산학협력을 위한 특성화 교육 관련 인력 인프라를 구축하는 역할까지도 담당하고 있다[7]. 따라서 산학 겸임교사의 역량이 군특성화고 학생의 역량 및 향후 군 복무자의 군사능력에도 영향을 미치기 때문에 군특성화고 산학 겸임교사 제도에 대한 면밀한 고찰을 통한 문제점과 개선방안을 도출할 필요가 있다.

한편 학교 교육의 주체는 교사와 학생이다. 학교는 학생이 하루 중 많은 시간을 
보내는 장소 중 하나이며, 교사는 학교생활 전반에 중요한 영향을 미친다. 아무리 훌륭한 교과서와 교육 방법이 있다 하더라도 수업에서 교수 활동을 최종적으로 수행하고 관리하는 것은 교사이다. 이러한 의미에서 현장에 있는 교사는 교육의 질과 학습자의 학습 성패를 좌우하는 핵심 주체로써 교육 현장에서 가장 중요한 요인이라 할 수 있다[8]. 군특성화고 산학 겸임교사는 군특성화반을 선택한 고3학생에게 단순한 교육과 훈련의 지도자를 넘어서서 군복무상담 및 군복무 후 진로상담까지도 담당할 수 밖에 없다. 따라서 군특성화반 학생에게 산학 겸임교사의 전문성, 수업, 군복무상담, 군복무 후 진로에 대한 상담 등에 대한 만족도는 군복무 및 군사능력 전반을 거쳐서 중요한 의미를 갖게 된다.

이처럼, 군특성화고 산학 겸임교사의 역할이 중요한 상황에서, 군특성화고 재학생이나 졸업생의 학교생활 및 군복무에서의 그 설치 목적에 맞도록 잘 기능하기 위해서는 산학 겸임교사에 대한 군특성화반 재학생 및 졸업생의 만족도와 산학 겸임교사의 수업, 군복무상담, 진로 상담 등의 내용의 군복무와 일치성 및 유용성에 관한 연구가 필요하다. 또한 군특성화고 겸임교사의 역할을 강화하기 위한 개선방안 역시 필요한 시점이라고 할 수 있다. 그럼에도 군특성화고 산학 겸임교사에 대한 연구는 박효성과 남기동[7]의 연구를 제외하고는 찾아보지 못하였다. 박효선과 남기동[7]은 산학 겸임교사의 입장에서 직무역량 및 직무 만족에 관심을 두었다. 김지한[9]은 군특성화고 졸업생을 대상으로 하여 직무만족도 영향요인을 연구하였는데, 이 연구 역시 졸업생의 입장에서 군인으로서의 직무만족도에 관심을 두었다. 일반 교사를 대상으로 한 연구를 보면, 교사의 수업전문성[10] 및 교사의 적극적인 수업 안내나 상담[11]은 학생의 학업성취도, 수업태도, 수업 만족도 등 다양한 요인에 영향을 미친다[8][12][13].

따라서 군특성화고의 중요성에 따른 산학 겸임교사의 업무 만족도는 단기적으로 군특성화고 재학생의 진로에 지대한 영향을 미칠 것이고, 장기적으로는 전문인력 양성의 최전선의 위치한 전문 군사 양성에도 영향을 미칠 것으로 예상되어, 군특성화고의 산학 겸임교사의 만족도 향상 및 제도 개선 방안에 대한 연구가 필요한 시점이다. 무엇보다, 군특성화고 산학 겸임교사에 관한 연구가 부족하여 학문적으로 알려진 바가 부족하여 문헌 고찰을 통해서 군특성화고 산학 겸임교사에 대한 면밀한 고찰과, 이로부터 개선방안을 제안할 필요가 있다. 따라서 군특성화고 산학 겸임교사 제도에 관한 문헌고찰도 필요하다.

이에 본 연구에서는 군특성화고에서 산학 겸임교사의 역할의 중요성을 감안하여, 첫째, 문헌고찰을 통해 군특성화고 산학 겸임교사 제도의 제한점을 도출하고, 둘째, 군특성화고 군특성화고 재학생과 졸업생(군복무자)을 대상으로 한 설문조사를 통해 군특성화고 산학 겸임교사에 대한 만족도, 정보 및 상담의 군복무에서의 일치성과 유용성, 산학 겸임교사 제도 개선방안을 분석함으로써, 군특성화고 산학 겸임교사 제도의 정착을 위한 제언을 하는데 연구의 목적이 있다.

\section{2. 연구방법}

본 연구에서는 산학 겸임교사 관련 법령 문헌 고찰과 군특성화고 재학생과 군특성화고 졸업 군복무자를 대상으로 한 설문조사를 병행한 통합연구 방법을 설계하였다. 


\section{1 군특성화고 산학 겸임교사 관련 법령 문헌 고찰}

군특성화고 산학 겸임교사 관련 제도는 군특성화고의 산학 겸임교사는 군인사법의 법률 근거에 바탕을 두고 있으며, 일반 산학 겸임교사는 초·중등교육법상의 법률적 근거를 두고 있다. 이에 따라 군특성화고 산학 겸임교사와 일반 산학 겸임교사간의 소속 및 관리, 인사, 복무 규정 등 다양한 차원에서의 차이를 밝힐 필요가 있어, 군특성화고 지원사업 운영지침, 초·중등교육법 제 19 조 제 1 항과, 초·중등교육법 시행령 제 42 조를 비교분석을 통한 문헌 고찰을 하였다.

\section{2 군특성화고 재학생과 군복무자 대상 자료수집}

\subsection{1 데이터}

본 연구의 연구대상은 총 두 집단이다. 군특성화반 재학생 747 명, 군복무자 116명(의무복무병 50명, 단기복무부사관 66명)으로써, 이수정 등[14]의 데이터 중 일부를 분석에 활용하였다. 이수정 등[15]은 2020년 12월 2021년 2월까지 1,249명을 대상으로 하여 한 설문조사를 실시하였다. 그 중 본 연구에서는 군특성화고 재학생과 군특성화고 졸업 군복무자의 데이터만을 선별하여 활용하였다. 군특성화고 재학생의 경우 전수조사를 목표로 하여 대상 학교의 산학 겸임교사의 협조를 얻었으며, 군복무자의 경우 국방부의 허가를 받아 조사되었다.

\subsection{2 측정 도구}

본 연구에서 사용된 측정 도구는 [표 1]과 같다. [표 1]에서 보는 바와 같이 군특성화고 재학생과 군복무자에게 공통의 문항도 있고 개별 특성에 맞는 문항도 있다. 분석에서 각 문항별 분석을 하였기 때문에, 신뢰도는 구하지 않았다.

[표 1] 측정도구

[Table 1] Measurement

\begin{tabular}{|c|c|}
\hline 대상 & 변수 \\
\hline $\begin{array}{l}\text { 재학생과 } \\
\text { 군복무자 } \\
\text { 공통문항 }\end{array}$ & $\begin{array}{l}\text {-개인적 특성 : 학과, 주특기, 주특기관련자격증소지 } \\
\text {-산학 겸임교사에 대한 만족도 :5점 리커트형 } 4 \text { 문항. 군관련전문성, 군관련수업,군복무상담, } \\
\text { 진로상담 만족도 } \\
\text {-진로만족도 : } 5 \text { 점 리커트형 척도, 단일문항 } \\
\text {-군특교사제도 개선방안 : } 5 \text { 점 리커트형 } 2 \text { 문항. 상담 역량강화 방안, 신분안정보장요구도 }\end{array}$ \\
\hline $\begin{array}{l}\text { 군복무자 } \\
\text { 단독문항 }\end{array}$ & $\begin{array}{l}\text {-정보의 일치성 : } 5 \text { 점리커트형 } 3 \text { 문항. 장기복무가능성, 훈련수당, 주특기분야에서의 정보일치성 } \\
\text {-군특성화고 추천: } 4 \text { 점 리커트형 척도, 단일문항: }\end{array}$ \\
\hline
\end{tabular}

\subsection{3 연구대상의 특성}

군특성화고 재학생은 모두 고등학교 3학년의 남학생으로써, 소속학과는 기계과가 $43.9 \%$ 로 가장 많았고, 정보/통신과가 $27.2 \%$, 전기/전자과가 $20.9 \%$ 순이었고, 주특기는 정보틍신이 $34.5 \%$, 기계정비가 $18.9 \%$, 항공이 $15.4 \%$ 순이었다. 주특기 관련 자격증 소지를 보면, 자격증이 있는 경우가 $82.3 \%$ 로 절대다수였고, $14.0 \%$ 는 준비할 예정이고, 
$9.5 \%$ 는 준비중에 있었다.

군특성화고 졸업 군복무자(의무복무병과 단기부사관)도 모두 남자이고, 연령을 보면, 의무복무병은 $86.0 \%$ 가 만 19 세이고, 단기복무부사관은 20 세가 $50.0 \%, 21$ 세가 $39.4 \%$ 였다. 의무복무병은 $98.0 \%$ 가 상병이었고, 단기복무부사관은 전원 하사였다. 출신학과는 의무복무병은 기계과가 $52.0 \%$, 정보/통신과가 $34.0 \%$ 로 대다수를 차지하며, 단기복무부사관도 기계과가 $69.7 \%$, 정보/통신과과 $10.6 \%$ 였다. 주특기는 의무복무병은 정보통신이 $42.0 \%$, 기계정비가 $22.03 \%$, 공병이 $8.0 \%$ 였고, 단기복무부사관은 기계정비가 $27.3 \%$, 정보통신이 $19.7 \%$, 공병이 $13.6 \%$ 순이었다. 주특기 관련 자격증 소지를 보면, 의무복무병은 $68.0 \%$ 가 자격증이 있고, 준비할 예정이라는 응답이 $14.0 \%$ 인 반면, 단기복무부사관은 자격증이 있는 경우는 $48.5 \%$ 이고, 준비할 예정은 $27.3 \%$, 자격증을 준비할 의향이 없다도 $13.6 \%$ 나 되었다.

\subsection{4 분석방법}

본 연구목적을 달성하기 위해 문헌분석과 SPSS Win 25.0 을 이용한 빈도분석, $\mathrm{t}$-test 를 적용 하였다.

\section{3. 연구결과}

\section{1 군특성화고 산학 겸임교사 제도와 제도의 제한점}

\subsection{1 군특성화고 산학 겸임교사 제도}

군특성화고 교원인사제도는 '군특성화고 교사'를 지칭하는데, 산학 겸임교사로서 해당 학교장의 통제를 받으며 국방부(각 군)의 군특성화고 지원사업 운영지침을 이행하는 역할을 한다. 산학 겸임교사는 해당 특기 분야의 군경력 15 년 이상인 자로써, 군특성화고 교사와 수석교사(평가관 겸직)으로 구분된다. 최초 선발 시 2 년 계약을 하며, 재계약 여부는 보조사업자의 장인 학교장이 결정하며, 60 세까지 근무할 수 있다. 군특성화고 교사 역할은 군특성화반 학생 선발을 보좌하며, 군에서 요구하는 맞춤형 전문기술인력을 양성하는 것이다. 수석교사는 군특성화고 공동과목에 순회교육을 실시하며, 교과서/교보재 개발 지원, 교사 직무연수 및 워크숍, 세미나 지원, 각군 본부 및 해당 학교는 공반기(방학기간)를 이용하여 군특성화고 교사의 직무능력 향상을 위한 교육을 실시하는 역할을 한다[6].

군특성화고 산학 겸임교사는 별도의 선발 절차를 거쳐 채용된다. 산학 겸임교사는 교원자격증이 있고 일반학교에서 근무하는 기간제 교원과는 달리, 특성화고, 마이스터고에서 근무를 하며 교원자격증을 소지하지 않아도 가능한 교사이다. 또한 예산지원과 관련하여서도 기간제교사는 교육청 예산으로서 활용이 되고 있으며, 군특성화고 산학 겸임교사는 별도의 선발절차를 거쳐 채용되기에 국방부에서 예산을 지원하고 있는 실정에 있다. 군특성화고의 특수성에 따라 군특성화고 산학 겸임교사의 자격 기준 또한 국방부에서 정하고 있다는데 차이가 있다 [6]. 제약제 교원의 한 형태인 기간제 교원, 산학 겸임교사, 군특성화고 산학 겸임교사를 구분해서 정리하면 [표 2]와 같다.

[표 2]에서 보는바와 같이 군특성화고 산학 겸임교사는 일반 산학 겸임교사와는 달리 국방부의 추천을 받은 교사를 학교장이 최종 선발하며, 임용기간 역시 일반 
산학겸임교사가 한기단위 혹은 수시 임용인 것과는 달리 2 년 근무 후 1 년 단위의 재계약을 하고 있다는 차이가 있다.

[표 2] 군 특성화고 교원 인사 관련 제도의 비교

[Table 2] Comparison of Personnel-related Systems for Military Specialized High School

\begin{tabular}{|c|c|c|c|c|}
\hline \multirow{2}{*}{\multicolumn{2}{|c|}{ 구분 }} & \multicolumn{3}{|c|}{ 계약제 교원 } \\
\hline & & 기간제 교원 & 산학 겸임교사 & 군특성화 산학 겸임교사 \\
\hline \multicolumn{2}{|c|}{ 소관관할 } & 시도교육청 & 시도교육청 & 국방부 \\
\hline \multicolumn{2}{|c|}{ 예산 근거 } & \multicolumn{2}{|c|}{$\begin{array}{c}\text { 기간제교원의 봉급 지급에 관한 예규 } \\
\text { 제1조(목적) 이 예규는 「공무원보수규정」 [별표 11]에 의해 } \\
\text { 교육부장관이 정하도록 한 기간제교원의 봉급 지급에 관한 } \\
\text { 구체적인 기준을 규정함을 목적으로 한다. } \\
\text { 제2조(적용대상) 이 예규는 「교육공무원법」 제 } 32 \text { 조 및 } \\
\text { 「사립학교법」제 } 54 \text { 조의4에 따른 기간제교원에게 적용한다. }\end{array}$} & 군특성화고 운영지침 \\
\hline \multirow{5}{*}{$\begin{array}{l}\text { 임 } \\
\text { 용 }\end{array}$} & 자격 & 해당 교원 자격증 소지자 & $\begin{array}{l}\text { 담당 과목 관련 분야 } \\
\text { 직무에 } 5 \text { 년 이상 근무 }\end{array}$ & $\begin{array}{c}\text { 군경력 } 15 \text { 년 이상, 담당과목과 } \\
\text { 관련되는 분야에서 } 3 \text { 년이상 } \\
\text { 근무 }\end{array}$ \\
\hline & 임용권 & 교육장(고등학교장) & $\begin{array}{l}\text { 학교장(단 중등 교사 } \\
\text { 자격자 초등 교과 전담 } \\
\text { 강사와 정원 미배정 } \\
\text { 유치원 강사는 교육장) }\end{array}$ & $\begin{array}{c}\text { 국방부는 ‘군특성화고 } \\
\text { 교사(전문교사 겸 평가관)'를 } \\
\text { 해당 군특성화학교로 추천 } \\
\text { 선발하여 학교에서 최종 선발 }\end{array}$ \\
\hline & 기간 & $\begin{array}{c}\text { 임용기간은 } 1 \text { 년의 범위 안에서 } \\
\text { 기간을 정하여 임용하되, 필요한 } \\
\text { 경우 } 3 \text { 년까지 연장 가능(총 } 4 \text { 년까지 } \\
\text { 임용 가능, 「교육공무원 임용령」 } \\
\text { 제 } 13 \text { 조 제 } 2 \text { 항) }\end{array}$ & $\begin{array}{c}\text { 학기 단위 또는 수시 } \\
\text { 임용 }\end{array}$ & $\begin{array}{c}\text { 계약 조건: 주 } 4 \text { 일제 근무 } \\
\text { 군특성화고 교사는 최초 선발 } \\
\text { 시 2년 계약 } \\
\text { 2년 근무실적을 평가 후 재계약 } \\
\text { 여부를 결정하며, 재계약은 } 1 \text { 년 } \\
\text { 단위 }\end{array}$ \\
\hline & $\begin{array}{l}\text { 상한 } \\
\text { 연령 }\end{array}$ & 교육공무원의 정년 62세와 동일 & 좌동 & 60세 \\
\hline & $\begin{array}{l}\text { 정원 } \\
\text { 관리 }\end{array}$ & $\begin{array}{c}\text { 정원 내에서 임명 } \\
\text { [단, 제 } 32 \text { 조 제 } 1 \text { 항 제 } 2 \text { 호(파견, 연수, } \\
\text { 직위해제 등)의 규정에 의한 } \\
\text { 기간제교원은 정원 외로 임명] }\end{array}$ & $\begin{array}{c}\text { 정원 외 임용 } \\
\text { (단, 중등교사 자격자 } \\
\text { 초등 교과 전담 강사는 } \\
\text { 정원 내) }\end{array}$ & 좌동 \\
\hline
\end{tabular}

\subsection{2 군특성화고 산학 겸임교사 제도의 제한점}

군특성화고 산학 겸임교사 제도의 제한점은 다음 4 가지로 집약이 된다. 첫째, 군특성화고 교사의 경우 자질을 평가하기 어려우며, 군을 전역한 예비역 장교들의 전역 후 일자리 마련을 위한 제도가 아니냐는 비판이 있다는 점이다. 「병역법」(2020.12.22. 개정 및 시행) 개정에 따라 「2021 년 「특성화고 군 지원사업」 운영계획」(발령 일자 2021.1.1.부터 유효기간 2021.12.31.까지)을 국방부 장관이 각 군 참모총장 및 해병대 사령관 각 (국직)부대장-기관장, 군특성화고등학교장이 수신하는 운영계획의 지침을 발신하였다[15]. 이 지침은 2021 학년도 특성화고 군 지원사업 이하 군특성화고 지원사업의 운영 및 관리에 관한 기준을 제시하고 있으며, 군이 필요로 하는 
전문기술인력을 양성하는 기술인력양성 사업 목적에 부합하도록 하는 데 목적이 있다고 하겠다. 그런데, 현재는 군특성화고에 맞는 전문인력의 군특성화고 교사를 채용하도록 해야 함에도 불구하고, 군특성화고의 특성에 부합하지 않는 군특성화 교사가 전문 수업을 지도하고 있어 관련 전문 분야 이외의 수업에는 분명한 한계가 존재하는 문제점이 있고, 관련 특성에 따른 역량의 질적 제고를 위한 지속적인 역량 강화도 반드시 필요하다.

둘째, 군특성화고 교사의 모집 및 임용의 권한은 특성화고 운영의 성격을 확보하고 있는 학교장의 권한을 더욱 확보해주어야 함에도 '해임(계약해지)'은 학교(장) 임의로 처리할 수 없도록 되어 있어 실질적인 임용 권한이 있다고 볼 수 없다는 문제가 제기된다. 국방부[6]의 「2021 년 “특성화고 군 지원사업” 지침」에서 “4. 업무 분장” “다. 직업계 특성화고 군 지원사업 학교장(보조사업자)'의 업무를 정하면서 군특성화고 담당 교수, 즉 수석 교사 겸 평가관에 대한 채용(임용) 및 운용에 관한 업무를 부여하고 있다. 하지만 현행 지침으로서는 군특성화고 담당교사의 임용에 있어서 '마. 교사의 채용 및 운용'을 검토해 보면, 국방부에서 '군특성화고 교사(수석교사 겸 평가관)'를 해당 군특성화고 학교로 4 배수 이내로 추천 선발하여 해 학교에서 최종 선발하도록 하고 있고, 2 년 계약을 하고 2 년 근무실적을 평가하여 재계약 여부를 보조사업자의 장인 학교장이 결정하도록 하고 있다. 군특성화고 교사의 임용 권한이 학교장에게 있는 것으로 보이나, ‘해임(계약해지)'은 학교(장) 임의로 처리할 수 없다. 사업의 연속성과 연장선 유지를 위해 '계약해지(해임) 사유 발생 즉시 국방부(각 군 본부)에 통보, 심의위원회 회부 등 해임 절차를 준수”하도록 규정되어 있고, “보조사업자의 장인 학교장이 국방부에 승인 절차 없이 임의로 군특성화고 교사를 해임할 수 없으며, 이를 위반할 경우 국방부(각 군 본부) $\leftrightarrow$ 학교 간 체결된 협약은 자동 해지한다.”라고 명시하고 있다. 보조사업자인 학교장이 권한을 행사하여 군특성화고 교사의 해임권을 사용하면 국방부와의 협약이 자동으로 해지된다고 규정하고 있어, 과연 학교장이 군특성화고 교사의 해임에 권한이 있는지 반문이 생긴다.

셋째, 현재 군특성화고는 43 개교, 73 개 학급으로 운영되고 있어[6], 군특성화고 산학 겸임교사의 수는 향후 계속 늘어날 것으로 보인다. 산학 겸임교사가 계속 늘어나고 있는 상황에서 일반 여타 산학 겸임교사와의 운영상의 차이가 나타날 수 있을 것으로 예상된다. 그 예로서 군특성화고 산학 겸임교사는 국방부에서 4 배수로 모집한 인원 중 학교장의 선택에 의해 선발되는 과정을 거치고, 또한 국방부 예산으로 운영되고 있는데 반해, 일반 여타 산학 겸임교사는 기간제교사와 마찬가지로 시도교육청에서 예산이 투여되고 있어 같은 제도가 관할 소관 차이로 인해 효과가 다르게 나타날 수 있다는 것이다. 군특성화교사는 군방부 예산으로 선발된다. 학교에서 교사의 역할을 하는 군특성화교사의 관리 및 지도에 있어서 관리영역은 시도교육청에 있지만, 예산은 국방부에서 지원하기 때문에 실제로 학교에서 관리감독이 효율적으로 이루어지기 어려운 구조다. 또한 군특성화교사는 일단 기간제 교사보다 오랜기간동안 학교에 계속 근무가 이어지고 있어 군특성화교사와 기간제 교사간의 불공평의 문제가 제기되어 국방부와 시도교육청에서 향후 문제로 제기될 소지가 크다고 하겠다.

넷째, 군특성화고 산학 겸임교사는 군특성화고를 운영하기 위한 필수인력이라고 할 수 있는데, 정규직이 아닌 계약직이라는 문제가 있다. 물론 시도교육청의 기간제 교원이 총 4 년까지 임용이 가능하나, 군특성화고 교사는 이러한 재임용 기간의 제한이 없다는 것이다. 그럼에도 군특성화고 교사의 임용 상한 연령이 60 세로 시도교육청이 선발하는 
기간제 교원 및 산학 겸임교사에 비해 낮다는 점에서 신분상의 불평등이 있다. 이에 대한 개선이 필요하다.

\section{2 군특성화고 재학생과 군복무자 대상 설문조사 결과}

\subsection{1 군특성화고 재학생과 군복무자의 산학 겸임교사에 대한 만족도의 차이}

군특성화고 재학생과 군복무자의 산학 겸임교사의 전문성, 수업 만족도, 군복무 상담만족도, 군복무 이후 진로상담만족도의 차이를 분석한 결과 만족도가 3 점 후반대에서 4 점 중반대까지로 상당히 높은 가운데, 군특성화고 재학생이 군복무자에 비해서 만족도가 더 높았다[표 3]. 즉, 군특성화고 재학생이 군특성화고 출신 군복무자에 비해서 산학 겸임교사의 전문성에 대한 만족도가 높고 $(\mathrm{t}=3.150, \mathrm{p}<.01)$, 수업에 대한 만족도가 높고 $(\mathrm{t}=3.617, \mathrm{p}=.001)$, 군복무상담에 대한 만족도가 높으며 $(\mathrm{t}=3.307, \mathrm{p}<.01)$, 군복무 이후 진로상담에 대한 만족도가 높았다(t=3.758, $\mathrm{p}<.01)$.

[표 3] 산학 겸임교사에 대한 만족도 차이

[Table 3] Differences in Satisfaction for Industry-Academic Adjunct Teachers

\begin{tabular}{|c|c|c|c|c|c|}
\hline & & $\mathrm{N}$ & Mean & S.D & $\mathrm{t}$ \\
\hline \multirow{2}{*}{$\begin{array}{l}\text { 전문성 } \\
\text { 만족도 }\end{array}$} & 재학생 & 747 & 4.28 & .885 & \multirow{2}{*}{$3.150^{* *}$} \\
\hline & 군복무자 & 116 & 3.91 & 1.223 & \\
\hline \multirow{2}{*}{$\begin{array}{l}\text { 수업 } \\
\text { 만족도 }\end{array}$} & 재학생 & 747 & 4.18 & .978 & \multirow{2}{*}{$3.617^{* * *}$} \\
\hline & 군복무자 & 116 & 3.75 & 1.215 & \\
\hline \multirow{2}{*}{$\begin{array}{l}\text { 군복무상담 } \\
\text { 만족도 }\end{array}$} & 재학생 & 747 & 4.20 & .959 & \multirow{2}{*}{$3.307^{* *}$} \\
\hline & 군복무자 & 116 & 3.82 & 1.199 & \\
\hline \multirow{2}{*}{$\begin{array}{c}\text { 군복무이후진로상담 } \\
\text { 만족도 }\end{array}$} & 재학생 & 747 & 4.16 & .985 & \multirow{2}{*}{$3.758^{* * *}$} \\
\hline & 군복무자 & 116 & 3.71 & 1.237 & \\
\hline
\end{tabular}

$* * \mathrm{p}<.01, * * * \mathrm{p}<.001$

이러한 산학 겸임교사에 대한 만족도의 차이는 진로 만족도에서도 드러났다[표 4]. 군특성화고 재학생이 군복무자에 비해서 현재의 진로에 대한 만족도가 높았다 $(\mathrm{t}=4.228$, $\mathrm{p}<.001)$.

[표 4] 진로 만족도의 차이

[Table 4] Differences in Career Satisfaction

\begin{tabular}{c|c|c|c|c|c}
\hline \multicolumn{2}{c|}{} & $\mathrm{N}$ & Mean & S.D & $\mathrm{t}$ \\
\hline \multirow{3}{*}{ 진로만족도 } & 재학생 & 747 & 4.05 & 1.003 & \multirow{2}{*}{$4.228^{* * *}$} \\
\cline { 2 - 5 } & 군복무자 & 116 & 3.56 & 1.182 & \\
\hline
\end{tabular}

$* * \mathrm{p}<.01, * * * \mathrm{p}<.001$ 


\subsection{2 군복무자가 지각하는 정보의 일치성과 유용성, 군특성화반 진학 추천의지}

군특성화고 졸업 군복무자를 대상으로 분석하였다. 고등학교 재학시기에 산학 겸임교사로부터 얻은 정보와 군생활을 하면서 얻게 된 정보와의 일치성을 파악해본 결과[표 5)], 2점 중반에서 3점 중반으로 정보의 일치도가 다소 낮다. 그 중에서 의무복무병이 단기복무부사관에 비해 훈련수당(급여)에 대한 정보의 일치성을 더 높게 평가하였다 $(\mathrm{t}=3.321, \mathrm{p}<.01)$.

\section{[표 5] 정보의 일치성}

[Table 5] Consistency of Information

\begin{tabular}{|c|c|c|c|c|c|}
\hline & & $\mathrm{N}$ & Mean & S.D & $\mathrm{t}$ \\
\hline \multirow{2}{*}{ 장기복무가능성 } & 의무복무병 & 50 & 3.24 & 1.021 & \multirow{2}{*}{1.463} \\
\hline & 단기복무부사관 & 66 & 2.94 & 1.149 & \\
\hline \multirow{2}{*}{ 훈련수당(급여) } & 의무복무병 & 50 & 3.38 & .901 & \multirow{2}{*}{$3.321^{* *}$} \\
\hline & 단기복무부사관 & 66 & 2.76 & 1.068 & \\
\hline \multirow{2}{*}{ 주특기분야일치성 } & 의무복무병 & 50 & 3.70 & .953 & \multirow{2}{*}{.639} \\
\hline & 단기복무부사관 & 66 & 3.58 & 1.096 & \\
\hline
\end{tabular}

$* * \mathrm{p}<.01$

다음으로는 군특성화고 졸업 군복무자가 고등학교 재학시기에 산학 겸임교사로부터 얻은 정보가 현재 군복무에서 유용한가를 파악해본 결과, 두 집단 모두 군 관련 정보의 유용성, 수업의 유용성, 상담의 유용성이 3점 후반대로 높았으나, 집단 간 차이는 통계적으로 유의하지 않았다(표로 제시하지 않음).

마지막으로 군복무자를 대상으로 하여 후배들에게 군특성화반 진학을 추천하겠는가를 질문한 결과[표 6], 4점 만점에 2점 중후반대로 중간정도의 수준을 보이는 가운데, 의무복무병이 단기복무부사관에 비해서 추천 의도가 더 높았다 $(\mathrm{t}=2.081, \mathrm{p}<.05)$.

[표 6] 군특성화반 진학 추천

[Table 6] Recommendation Level for Admission to Military Specialized High School

\begin{tabular}{c|c|c|c|c|c}
\hline \multicolumn{2}{c|}{} & $\mathrm{N}$ & Mean & S.D & $\mathrm{t}$ \\
\hline $\begin{array}{c}\text { 군특성화반 } \\
\text { 진학 추천 }\end{array}$ & 의무복무병 & 50 & 2.98 & .915 & \multirow{2}{*}{$2.081^{*}$} \\
\cline { 2 - 6 } & 단기복무부사관 & 66 & 2.61 & .990 & \\
\hline${ }^{* p<.05}$
\end{tabular}

\subsection{3 군특성화고 재학생과 군복무자의 산학 겸임교사 역량강화를 위한 제도개선방안의 차이}

군특성화고 재학생과 군복무자의 산학 겸임교사의 상담역량 전문성 강화와 신분안정보장에 대한 필요성을 분석한 결과[표 7], 3점 후반대에서 4점 중반대까지로 상당히 높은 가운데 군복무자가 재학생에 비해 제도개선이 더 필요함을 피력하고 있었다. 즉 군복무자가 재학생에 비해서 산학 겸임교사의 상담역량 전문성 강화가 
필요하며 $(\mathrm{t}=3.171, \mathrm{p}<.01)$, 신분안정도 보장될 필요가 있다 $(\mathrm{t}=2.385, \mathrm{p}<.05)$ 고 보고 있었다.

[표 7] 산학 겸임교사 역량강화를 위한 제도 개선

[Table 7] Improvement of the System to Strengthen the Competency

\begin{tabular}{c|c|c|c|c|c}
\hline \multicolumn{2}{c|}{} & $\mathrm{N}$ & Mean & S.D & $\mathrm{t}$ \\
\hline \multirow{2}{*}{$\begin{array}{c}\text { 산학 겸임교사의 } \\
\text { 상담 역량강화 }\end{array}$} & 재학생 & 747 & 3.88 & 1.005 & \multirow{2}{*}{$\mathrm{t}=-3.171^{* *}$} \\
\cline { 2 - 5 } & 군복무자 & 116 & 4.20 & 1.023 & .971 \\
\multirow{2}{*}{$\begin{array}{c}\text { 산학 겸임교사의 } \\
\text { 신분안정 보장 }\end{array}$} & 재학생 & 747 & 3.88 & \multirow{2}{*}{$\mathrm{t}=-2.385^{*}$} \\
\cline { 2 - 5 } & 군복무자 & 116 & 4.11 & 1.053 & \\
\hline
\end{tabular}

${ }^{*} \mathrm{p}<.05,{ }^{* *} \mathrm{p}<.01$

\section{4. 요약 및 제언}

본 연구에서는 군특성화고에서 산학 겸임교사의 역할의 중요성을 감안하여, 첫째, 군특성화고 산학 겸임교사 제도의 제한점을 도출하고, 둘째, 군특성화고 군특성화고 재학생과 졸업 군복무자를 대상으로 하여 군특성화고 산학 겸임교사에 대한 만족도, 정보 및 상담의 군복무에서의 일치성과 유용성, 산학 겸임교사 제도 개선방안을 분석함으로써, 군특성화고 산학 겸임교사 제도의 정착을 위한 제언을 하는에 연구의 목적이 있었다. 이를 위해 산학 겸임교사 관련 법령을 문헌 고찰하고, 이수정 등[14]의 데이터 중 일부를 활용하여 통계분석을 하였다. 그 결과 주요 연구 결과를 중심으로 설명하면, 첫째, 군특성화고 산학 겸임교사의 자질평가가 어려우며, 교사의 모집 및 운영에서 학교장의 권한이 약함, 다른 산학 겸임교사와의 형평성 문제, 필수인력의 계약직으로 운영의 문제점이 발견되었다. 둘째, 산학 겸임교사의 전문성이나 수업, 상담에 대한 만족도는 군특성화고 재학생이 더 높았으나, 산학 겸임교사의 역량 강화나 신분안정보장은 군복무자가 좀 더 높게 요구하고 있었다. 또한, 졸업한 군복무자는 고등학교 때 얻은 군복무에 대한 정보와 현재 상황 간의 정보의 일치성이 다소 낮게 평가하였다. 이러한 연구 결과를 토대로 다음 2 가지 측면에서의 제언을 하면 다음과 같다.

\section{1 군특성화고 산학 겸임교사 제도 개선방안}

첫째, 학교장의 군특성화고 산학 겸임교사에 대한 임용 권한 강화 등 학교 역할을 확대할 필요가 있다. 군특성화고 교사의 모집 및 임용과 관련해서는 특성화고 운영의 성격을 확보하고 있는 학교장의 권한을 더욱 강화해 줄 필요가 있다. 이와 함께 국방부에서 4 배수로 뽑아서 학교장이 임용할 수 있도록 추천한다고 하지만, 그러한 추천의 신뢰도를 확보할 필요가 있다. 즉, 국방부 내부에서 어떤 자격을 갖춘 자를 뽑는지 혹은 민간전문가가 참여하는지 등에 대한 정보를 공개함으로써 신뢰도를 확보할 필요가 있다. 따라서 군특성화고 채용 공고 및 과정 공개, 민간전문가 참여 등을 가능하게 하고, 군특성화고 교사의 선발-임용-채용-관리 등 일련의 선발 과정, 선발 이후 역량의 평가를 학교장 및 학교 구성원이 실시할 필요가 있다. 
둘째, 군특성화고 산학 겸임교사 연수를 통한 역량을 강화할 필요가 있다. 군특성화고 교사 대상 역량 강화 연수를 통해 직업계고 교육과정 편성·운영에 대한 특성, 학생에 대한 이해 및 상담, 교수법 등 군 기술교육과 일반 군사교육을 지도할 수 있는 역량 함양 등을 위한 연수 기회 제공함으로써 전문 교사의 자질 함양 및 지속적 신분보장을 위한 역량을 강화할 필요가 있다. 이를 위해서는 국방부와 시도교육청에서 지속적으로 관심있게 살펴보고 교육 현장의 질적 제고를 위한 제도개선을 합의할 필요가 있다.

셋째, 군특성화고 산학 겸임교사 선발-임용-채용-관리의 질 제고 방안과 신분 안정을 위한 법적 근거를 마련해야 한다. 현재는 국방부[6]의 "2021년 군특성화고 운영지침" 에 따른 선발을 하고 있다. 지침이라는 것은 내부교율로서 외부 효력이 없다고 보는 것이 합리적인데, 이러한 ‘군특성화고 운영지침'을 통해 군특성화고 산학 겸임교사를 선발하고 관리한다는 법적용에서의 한계가 있음을 확인 할 수 있다. 군특성화교사의 선발-임용채용-관리를 위한 근거적인 법률로서 상향하여 위치하는 것이 합리적이라고 할 것이다. 이러한 근거법적인 내용은 “군인사법”에 군특성화 교사를 두도록 명시하고 그에 대한 구체적인 내용은 “군특성화고 운영지침”을 따르도록 하는 것이 합리적이라고 하겠다.

\section{2 군특성화고 산학 겸임교사에 대한 만족도 향상방안}

첫째, 군특성화고 산학 겸임교사의 전문성, 수업, 군복무 상담, 진로 상담에 대한 만족도는 상당히 높았고, 군특성화고 재학생이 군복무자에 비해 이러한 만족도가 더 높았다. 이러한 만족도와 같은 선상에서 현재 군특성화고 재학생이 군복무자에 비해 진로 만족도도 더 높았다. 따라서 산학 겸임교사가 현재의 재학생을 대상으로 한 적극적인 정보제공과 상담을 통해서 학생들의 진로 만족도를 향상시킨다면, 궁극적으로는 군에서 필요로 하는 인적 자원의 획득도 안정화 될 수 있을 것이다. 그러나 현재 군특성화고 산학 겸임교사는 고등학생들 상담하기에 적합하지 못하다. 산학 겸임교사는 군경력 15 년 이상과 담당 교과 3 년 이상의 경력자이기 때문에 군 생활과 관련된 정보제공과 상담은 가능할 것이나, 다양한 진로 상담은 어려울 수 있다. 따라서 산학 겸임교사의 학생 상담 능력을 향상시킴과 동시에 군특성화고에 상담 전담 교사를 배치할 필요가 있다. 이를 위해서는 군특성화교사가 군특성화반 재학생에게 보다 다양한 상담내용을 제공하기 위한 역량 강화 교육도 필요하고 이를 통해 군특성화고 학생들의 군특성화 교사의 만족도 향상에도 도움이 될 것이며, 군특성화교사의 직무만족도 향상에도 크게 도움이 될 것으로 판단된다.

둘째, 군특성화고 졸업 군복무자는 고등학교 때 산학 겸임교사로부터 얻는 군관련 정보와 현재 군에서 알게된 정보 간의 일치성을 다소 낮게 인식하고 있었는데, 단기복무병이 의무복무병에 비해서 정보의 일치성을 낮게 평가했고 군특성화반 진학 추천 의지도 낮았다. 단기복무부사관은 재학생이나 의무복무병에 비해서 주특기 관련 자격증 취득 수준도 낮았고, 심지어 주특기 관련 자격증을 취득할 예정이 없다는 비율도 높았다. 따라서 군특성화고 제도가 좀 더 안정적으로 운영되기 위해서 가장 시급한 것은 군복무중인 단기복무부사관을 대상으로 한 군생활 적응을 위한 상담과 장기복무부사관으로의 진로연계를 위한 교육 및 상담이 우선되어야 한다는 점을 제안한다. 박효선과 남기동[7]도 군특성화고 산학 겸임교사의 전문성 강화를 위한 연수를 강조하였는데, 이러한 연수에는 군관련 연수만이 아닌 교사로서의 학생상담 관련 내용도 포함될 필요가 있다고 주장하였고 본 연구결과와 같은 맥락이다. 
셋째, 산학 겸임교사의 전문성이나 수업, 상담에 대한 만족도는 군특성화고 재학생이 더 높았으나, 산학 겸임교사의 역량강화나 신분안정보장은 군복무자가 좀 더 높게 요구하고 있었다. 결국 산학 겸임교사에 대한 만족도가 낮았기 때문에 이들의 상담역량 강화를 위한 요구도가 높은 것은 당연하나, 산학 겸임교사의 신분안정을 위한 불안정한 신분을 안정화 시킬 필요성도 높게 인식하고 있었다. 이처럼 군특성화고 산학 겸임교사의 안정적인 신분보장이 필요하다는 점은 박효선과 남기동[7]의 연구와 일맥상통한다. 군복무자는 군생활을 하면서, 산학 겸임교사의 상담, 교육이 안정적이고 이를 통해서 고등학교 재학시절 얻은 다양한 정보가 군복무 중에 알게 된 정보와 일치하고 유용성을 갖기 위해서는 결국 산학 겸임교사의 역량 향상과 더불어 신분안정이 중요하다고 인식하고 있는 것으로 볼 수 있다.

이처럼 본 연구에서는 군특성화고 제도의 정착을 위해 핵심적인 역할을 하고 있는 산학 겸임교사제도와 산학 겸임교사에 대한 재학생과 군복무자의 만족도를 분석함으로써, 산학 겸임교사제도의 개선방안을 제안했다는점에서 의의가 있다. 그러나 산학 겸임교사를 본 연구대상자로 포함시키지 못하였기 때문에 이들의 입장에서 제도개선 방안이 다소 제한적일 수 있다. 이에 향후 연구에서는 산학 겸임교사을 대상으로 하여 제도 개편방안을 연구할 필요성이 있음을 제안한다.

\section{References}

[1] https://kookbang.dema.mil.kr/newsWeb/20190829/5/BBSMSTR_000000010021/view.do, Jan 20 (2021)

[2]https://www.mnd.go.kr/cop/pblictn/selectPublicationUser.do?siteId=mnd\&componentId=14\&categoryId=15\&publicat ionSeq=897\&pageIndex=1\&id=mnd_040501000000, Jan 20 (2021)

[3] https://kookbang.dema.mil.kr/newsWeb/20190109/1/BBSMSTR_000000100003/view.do, May 15 (2021)

[4] http://www.mnd-hs.org/main.php, Feb 07 (2021)

[5] J. S. Oh, Career Counseling Teacher's Perception of the Roles and Tasks: The Analysis of Importance and Performance, The Journal of Career Education Research, (2014), Vol.27, No.2, pp.41-64, UCI: G704-001285.2014.27.2.007

[6] 2021 Specialized High School Military Support Project Operation Plan, Ministry of National Defense, pp.7-16, (2021)

[7] H. S. Park, K. D. Nam, A Study on the Recognition of Job Competence and Job Satisfaction of Joint Industry-academy Teachers in the Military Specialized High School, The Journal of Vocational Education Research, (2019), Vol.38, No.5, pp.1-22, DOI: 10.37210/JVER.2019.38.5.1

[8] J. Y. Chang, I. W. Park, E. J. Kim, The Effects of Teaching Method and Homework Feedback on Students' Class Attitude, Classroom Atmosphere, Class Satisfaction, Self-Directed Learning, and Academic Achievement, Teacher Education Research, (2018), Vol.57, No.2, pp.246-259, DOI: 10.15812/ter.57.2.201806.246

[9] J. H. Kim, A Study on the Factors Affecting Job Satisfaction of the Graduates of Military Specialized High School, Cheong Ju University, Doctoral dissertation, p.59, (2020)

[10] K. Y. Park, A Structural Analysis of Effect Factors on Teachers' Teaching Professionalism, The Journal of Educational Administration, (2008), Vol.26, No.2, pp.49-74. UCI: G704-000511.2008.26.2.003

[11] S. H. Kim, M. J. Kim, The Effects of Types of Instructor Facilitation on Learners' Social Presence, Interaction, Satisfaction, and Learning Achievement in an Asynchronous Web-Based Discussion, Journal of Korean Association for Educational Information and Media, (2006), Vol.12, No.3, pp.299-321, UCI: G704-000750.2006.12.3.006

[12] H. Y. Noh, W. S. Sohn, The Role of Teacher-provided Feedback on Homework in Student Engagement and Academic Achievement, Journal of Educational Evaluation, (2015), Vol.28, No.3, pp.879-902, UCI: G704-000051.2015.28.2.011 
[13] S. Y. Shin, J. S. Kim, Investigating the structural relationship among factors affecting perceived class, perceived class, learning outcomes, and education satisfaction, The Journal of Learner-Centered Curriculum and Instruction, (2016), Vol.16, No.11, pp.383-402, DOI: 10.22251/jlcci.2016.16.11.383

[14] S. J. Lee, Y. J. Hur, M. R. Lee, K. W. Song, Y. J. Kim, S. H. Park, A Plan to Improve the Operation of Military Specialized High Schools, Korea Vocational Competency Development Institute, Korea Scholarship Foundation, pp.100-101, (2021), https://www.krivet.re.kr/ku/da/kuBAAVw.jsp?gn=E1-E120210190

[15] 2021 Specialized High School Military Support Project Operation Plan, Ministry of National Defense, pp.1-2, (2021) 